\title{
Genetic characterization of the lobster pathogen Aerococcus viridans var. homari by 16S rRNA gene sequence and RAPD
}

\author{
Spencer J. Greenwood*, Ian R. Keith, Béatrice M. Després, Richard J. Cawthorn \\ AVC Lobster Science Centre, Atlantic Veterinary College, University of Prince Edward Island, Charlottetown, \\ Prince Edward Island C1A 4P3, Canada
}

\begin{abstract}
A combination of 16S rRNA sequencing and random amplified polymorphic DNA (RAPD) analysis was used to evaluate the genetic diversity within Aerococcus viridans var. homari, the causative agent of gaffkemia in lobsters. A collection of 7 A. viridans var. homari strains and 2 avirulent $A$. viridans-like cocci isolated from homarid lobsters harvested from different regions on the Atlantic Coast of North America were analyzed. The isolates are separated geographically and temporally between the years 1947 and 2000. Sequencing of 16S rRNA genes confirmed the inclusion of all 9 isolates in the monophyletic $A$. viridans clade (99.8 to $100 \%$ similarity). RAPD analysis revealed that the $9 \mathrm{~A}$. viridans var. homari isolates could be separated into 2 distinct subtypes. Subtype 1 included the 7 pathogenic lobster isolates and constituted a homogeneous group regardless of their geographical, temporal or virulence differences. Subtype 2 contained the 2 avirulent $A$. viridans-like cocci that had distinct RAPD patterns and clustered separately with the non-marine A. viridans. RAPD analysis represented a useful method for determining molecular subtyping for the intraspecific classification and epidemiological investigations of $A$. viridans var. homari.
\end{abstract}

KEY WORDS: Lobster · Homarus americanus · Gaffkemia · Aerococcus viridans var. homari - RAPD · 16S rRNA

\section{INTRODUCTION}

Aerococcus viridans var. homari is the causative agent of gaffkemia, a systemic disease of homarid lobsters (Homarus americanus and $H$. gammarus) found in the coastal waters of both North America and Europe (Wood 1965a, Stewart et al. 1966, Audouin \& Léglise 1971). However, it is within the commercial lobster industry where the major economic impact of gaffkemia occurs, because the disease contributes significantly to post-harvest losses (Stewart 1980). Gaffkemia was first described in dying American lobsters from a holding unit in Maine in 1947, and subsequently the bacterium $A$. viridans var. homari (originally named Gaffkya homari) was isolated and Koch's postulates fulfilled (Hitchner \& Snieszko 1947, Snieszko \& Taylor 1947). Subsequently, considerable research effort has documented the biology of $A$. viridans var. homari and the impact of gaffkemia on the commercial lobster industry (reviewed by Stewart 1993).

Aerococcus viridans var. homari enters the lobster through breaks in the integument caused by fighting, overcrowding and poor handling practices after capture and during transport (Stewart 1980). Typically, after the lobster's exoskeleton is breached, a fatal septicemia ensues as virulent strains of $A$. viridans var. homari appear resistant to the lobster's innate immune response (Stewart 1980). Nevertheless, virulent strains of A. viridans var. homari maintained in vitro lose the capacity to cause disease in lobsters upon re-infection (Stewart 1984, Stewart et al. 2004). Although the exact mechanisms of virulence and its subsequent loss through continuous passage in vitro are unknown, it 
appears to be correlated with the presence and thickness of the polysaccharide capsule (Stewart 1984, Stewart et al. 2004).

On rare occasions, avirulent Aerococcus viridanslike cocci have been isolated from lobsters (Wood 1965b, Stewart et al. 1966, Rabin \& Hughes 1968, Stewart et al. 2004). These cocci share many phenotypic characteristics with virulent $A$. viridans var. homari but were unable to cause disease in lobsters (Stewart et al. 1966). Previous genotypic characterizations using DNA-DNA hybridization indicated that $A$. viridans var. homari was sufficiently similar to be placed in the same taxon as environmental and human clinical isolates of A. viridans (Kelly \& Evans 1974, Wiik et al. 1986, Bosley et al. 1990). However, the genetic relationship of the avirulent $A$. viridans-like cocci to the lobster pathogen A. viridans var. homari has remained unresolved (Wiik et al. 1986).

The application of molecular subtyping methods that allow for the characterization of genetic diversity within bacterial species and strains has shown considerable value for the study of intraspecific classification and for epidemiological investigations. The ability to differentiate subtypes is important for the recognition of disease outbreaks, the determination of sources of infection, the detection of particularly virulent strains and host distribution and geographical origin of possible variants of a specific pathogen (Olive \& Bean 1999, Soll 2000). The available molecular methods used for subtyping differ widely in their ability to differentiate among strains (Soll 2000). The comparison of $16 \mathrm{~S}$ rRNA gene sequences has been recognized as an invaluable tool for confirming bacterial species identity but not for differentiating among strains, since the sequence shows limited intraspecific variation (Bottger 1989, Olsen \& Woese 1993, Drancourt et al. 2000). In contrast, randomly amplified polymorphic DNA (RAPD) analysis is a sensitive PCR-based method that uses arbitrary primers to generate whole genome DNA fingerprints for discriminating between strains (Welsh \& McClelland 1990, Williams et al. 1990). The recent advent of standardized and optimized reagents has greatly improved the accessibility and reproducibility of the RAPD method (Hyytiä et al. 1999). These improvements led to an increase in the number of successful applications of the RAPD method for differentiating strains of marine bacterial pathogens (Romalde et al. 1999, 2002, Magariños et al. 2000, Ravelo et al. 2003).

In this study, a combination of 16S rRNA sequencing and RAPD analysis was used to characterize the genetic diversity within Aerococcus viridans var. homari. A collection of 7 A. viridans var. homari strains and 2 avirulent $A$. viridans-like cocci isolated from homarid lobsters harvested from different regions on the Atlantic Coast of North America were analyzed. The isolates are separated geographically and temporally between the years 1947 and 2000. The usefulness of RAPD analysis for intraspecific classification and epidemiological studies of Aerococcus viridans var. homari was evaluated.

\section{MATERIALS AND METHODS}

Bacterial strains. Aerococcus viridans var. homari strains included in this study (Rabin, NVI 1030 and NVI 1032) and 2 A. viridans-like cocci (37R and 88B) were kindly provided by Dr. J. E. Stewart, (Department of Fisheries and Ocean, Bedford Institute of Oceanography, Dartmouth, NS, Canada). In addition, A. viridans var. homari strains (ATCC 10400 and 29838) and a non-marine $A$. viridans isolate (ATCC 700406) were obtained from the American Type Culture Collection (ATCC, Manassas, VA, USA). Two purified A. viridans var. homari isolates (Newfoundland and Maine) derived from lobster pathology cases submitted to the Atlantic Veterinary College from commercial holding pounds were also included (Table 1).

The strains were routinely cultured on tryptic soy agar (TSA, Oxoid) at $28^{\circ} \mathrm{C}$ for $24 \mathrm{~h}$. Stock cultures were stored at $-80^{\circ} \mathrm{C}$ in trypticase soy broth (TSB, Oxoid) supplemented with $15 \%$ (v/v) glycerol.

Phenotypic characterization. Standard identification of aerococci includes Gram-reaction, cell morphology and arrangement, motility, catalase, hemolysis, hydrolysis of hippurate and esculin, deamination of arginine, utilization of pyruvate and sensitivity to $30 \mu \mathrm{g}$ vancomycin disc (Facklam \& Elliott 1995). Growth was assessed at $10^{\circ} \mathrm{C}, 45^{\circ} \mathrm{C}$, and at $\mathrm{pH} 9.6$ (Facklam \& Elliott 1995). Other physiological tests recommended are salt ( 6.5 and $10 \% \mathrm{NaCl})$, bile $(40 \%)$ and tellurite $(0.04 \%)$ tolerance (Facklam \& Elliot 1995). Glucose oxidation/fermentation followed (Lemos et al. 1985), while additional carbohydrate fermentations (fructose, galactose, maltose, melibiose, sucrose, glycerol, sorbitol, and inulin) were tested by conventional tube test (Facklam \& Elliott 1995). L-arabinose, D-mannitol, Dlactose, D-raffinose, and glycogen were tested by the Analytical Profile Index (API) 20 Strep product (Fertally \& Facklam 1987). The isolates were further tested for production of 1-pyrrolidonyl- $\beta$-arylamidase (PYR), leucine aminopeptidase (LAP) (Bosley et al. 1990) and other enzymes by the API 20 Strep and API ZYM products (BioMérieux). Additionally, the production and detection of acetoin (MacFaddin 1980, Fertally \& Facklam 1987), nitrate reduction (MacFaddin 1980) and gelatin liquefaction (Facklam 1972) were evaluated.

Each isolate in the study was passed on TSA (Oxoid) at $28^{\circ} \mathrm{C}$ at least 3 times before serving as seed inocu- 
lum for broth or agar plate growth for phenotypic tests. Twenty-four hour growth on TSA (Oxoid) or Columbia blood agar (BA) (Oxoid), supplemented with $5 \%$ defibrinated sheep's blood, were the inocula for the API and heart infusion broth-based tests, respectively. Appropriate positive and negative control isolates used were as described by Cowan et al. (1993).

Genomic DNA extraction. Bacterial colonies were picked from TSB plates for inoculation of liquid media. Bacteria were grown in TSB supplemented with $3 \%$ (w/v) $\mathrm{NaCl}$ at $28^{\circ} \mathrm{C}$ for $24 \mathrm{~h}$. DNA was extracted using the GenElute ${ }^{\mathrm{TM}}$ Bacterial Genomic DNA kit (SigmaAldrich) supplemented with mutanolysin (250 $\mathrm{U} \mathrm{l}^{-1}$, Sigma-Aldrich). DNA concentration was determined both spectrophotometrically and by an ethidium bromide-spot assay (Sambrook et al. 1989). Quality of the genomic DNA was assessed by electrophoretic separation in a $0.8 \%$ agarose gel containing $0.5 \mu \mathrm{g} \mathrm{ml}^{-1}$ ethidium bromide.

PCR amplification and sequencing of 16S rRNA genes. The 16S rRNA gene of all 10 bacterial isolates was amplified using modified versions of the universal bacterial primers BSF-8/20 (5'-AGAGTTTGATCCTGGCTCAG-3'), positions 8 to 27 in the Escherichia coli 16S rRNA gene and BSR-1541/20 (5'-AAGGAGGTGATCCAGCCGCA-3'), E. coli positions 1541 to 1522 (for both primers the polylinker regions were removed) (Weisburg et al. 1991, Daly et al. 1993, Wuyts et al. 2002). Approximately $10 \mathrm{ng}$ of bacterial genomic DNA was amplified in a $50 \mu \mathrm{l}$ reaction containing $10 \mathrm{pmol}$ of each primer BSF-8/20 and BSR-1541/20 in the presence of the following reagents (Fermentas International), $200 \mu \mathrm{M}$ of each dNTP (A, G,C and T), $1.5 \mathrm{mM}$ $\mathrm{MgCl}_{2}, 1 \times$ PCR buffer (10 mM Tris, $\mathrm{pH} 8.8,50 \mathrm{mM} \mathrm{KCl}$ and $0.08 \%$ Nonidet P40) and 1.25 U of Taq DNA polymerase. A negative control, consisting of the same reaction mixture but with molecular biology grade water (Sigma-Aldrich) instead of template DNA, was included in each run. The amplification protocol was carried out in a MJ Research PTC-200 thermal cycler (MJ Research) under the following conditions: an initial denaturation at $94^{\circ} \mathrm{C}$ for $2.5 \mathrm{~min}$, followed by 25 cycles consisting of denaturation at $94^{\circ} \mathrm{C}$ for $1 \mathrm{~min}$, annealing at $45^{\circ} \mathrm{C}$ for $1 \mathrm{~min}$, and extension at $72^{\circ} \mathrm{C}$ for $1.5 \mathrm{~min}$. Final extension was at $72^{\circ} \mathrm{C}$ for $5 \mathrm{~min}$. The amplified DNA was purified using a GenElute ${ }^{\mathrm{TM}}$ PCR clean-up kit (Sigma-Aldrich) and separated by electrophoresis in a $0.8 \%$ agarose gel containing $0.5 \mu \mathrm{g}$ $\mathrm{ml}^{-1}$ of ethidium bromide. Direct sequencing of purified PCR products was performed on an ABI Prism 377 sequencer using Big-Dye $\mathrm{TM}^{\mathrm{TM}}$ terminators (Applied Biosystems) at the Guelph Molecular Supercentre (Laboratory Services Division, University of Guelph, ON, Canada). Sequencing primers were derived from a 16S rRNA primer collection at the European Ribosomal RNA Database (http://oberon.fvms.ugent.be:8080/ rRNA/index.html, Wuyts et al. 2002). Forward sequencing primers used were BSF-8/20 and BSF-784/16 (5'-AGGATTAGATACCCTG-3') E. coli positions 784 to 799 and reverse sequencing primers BSR-1541/20 and BSR-799/16 (5'-CAGGGTATCTAATCCT-3') E. Coli positions 799 to 784 .

The 16S rRNA sequences were assembled by manual alignment using Bio-Edit (Hall 1999) incorporating the published Aerococcus viridans 16S rRNA sequence (ATCC 1156, GenBank accession number M58797) as a guide. To ensure homogeneous single-species sequence information prior to phylogenetic reconstruction, all 16S rRNA sequence electropherograms were carefully examined to ensure that only single peaks and therefore single species DNA was amplified and sequenced (Drancourt et al. 2000). Sequences were further screened for

Table 1. Aerococcus viridans isolates used in the present study

\begin{tabular}{|c|c|c|c|c|}
\hline Isolate & Identification & Origin & Location, Year of isolation & Virulence status $^{a}$ \\
\hline ATCC $10400^{\mathrm{b}}$ & A. viridans var. homari & Homarus americanus & Maine, USA, 1947 & Avirulent \\
\hline ATCC $29838^{\mathrm{c}}$ & A. viridans var. homari & Homarus americanus & England & Virulent \\
\hline Rabin & A. viridans var. homari & Homarus americanus & Massachusetts, USA, 1963 & Virulent \\
\hline Newfoundland & A. viridans var. homari & Homarus americanus & Newfoundland, Canada, 1991 & Virulent \\
\hline Maine & A. viridans var. homari & Homarus americanus & Maine, USA, 2000 & Virulent \\
\hline NVI $1030^{\mathrm{d}}$ & A. viridans var. homari & Homarus americanus & NVI, Norway, 1977 & Virulent \\
\hline NVI $1032^{\mathrm{d}}$ & A. viridans var. homari & Homarus americanus & NVI, Norway, 1977 & Virulent \\
\hline $37 \mathrm{R}$ & A. viridans-like coccus & Homarus americanus & Prince Edward Island, Canada, 1964 & Avirulent \\
\hline 88B & A. viridans-like coccus & Homarus americanus & Nova Scotia, Canada, 1962 & Avirulent \\
\hline ATCC $700406^{\mathrm{e}}$ & A. viridans & Environment & Not reported & Avirulent \\
\hline $\begin{array}{l}{ }^{\mathrm{a}} \text { Virulence statu } \\
\text { b Original isolate } \\
{ }^{\mathrm{c}} \text { Origin likely N } \\
{ }^{\mathrm{d}} \text { National Veter } \\
{ }^{\mathrm{e}} \text { BioMerieux Vit }\end{array}$ & $\begin{array}{l}\text { at time of the present stu } \\
\text { of Sniesko \& Taylor (1947 } \\
\text { rth America (J. E. Stewar } \\
\text { ary Institute, Norway- } \\
\text { k, Inc. (API 78-12-095) - }\end{array}$ & $\begin{array}{l}\text { virulent at time of isolat } \\
\text { ers. comm.) } \\
\text { ected lobsters imported } \\
\text { ality control strain for }\end{array}$ & $\begin{array}{l}\text { om St. Lawrence area, Canada, } 1977 \\
\text { l products }\end{array}$ & \\
\hline
\end{tabular}


the presence of chimeric sequence using the programs Chimera Check (Maidak et al. 1999, Cole et al. 2003) and Bellerophon (Hugenholz \& Huber 2003).

16S rRNA phylogenetic analysis. The following sequences were obtained from GenBank: Aerococcus viridans (accession no. M58797) (Woese et al. unpubl.), uncultured feedlot manure bacterium B87 (AF317386) (Ouwerkerk \& Klieve unpubl.), Aerococcus sp. LV 65.5:W1 (AF076639) (Bratina et al. 1998), Pediococcus urinaeequi (D87677) (Nageshima unpubl.), bacterium B16S (AF300974) (Allen et al. 2001), Aerococcus urinaehominis (AJ278341) (Lawson et al. 2001a), Aerococcus christensenii (Y17005) (Collins et al. 1999), Aerococcus urinae (M77819) (Aguirre \& Collins 1992), Aerococcus sanguicola (AJ276512) (Lawson et al. 2001b), Facklamia hominis (Y10772) (Collins et al. 1997).

Sequences were analyzed with programs in the Ribosomal Database Project-II (RDP-II) (Maidak et al. 1999, Maidak et al. 2001, Cole et al. 2003). Sequences were aligned using the conserved 16S rRNA secondary structure. Phylogenies were reconstructed using PHYLIP (Felsenstein 1993) with a similarity matrix computed by the method described by Kimura (1980) and a dendrogram via neighbor-joining (Saitou \& Nei 1987). The constructed Aerococcus viridans RDP-II alignment was then imported into MEGA-2 (Molecular Evolutionary Genetics Analysis-2) (Kumar et al. 2001) software for phylogenetic analysis using neighborjoining (Kimura 2-parameter with gaps and missing data handled by complete deletion) and maximum parsimony. Statistical evaluation of phylogenetic tree branching order was bootstrap resampled 1000 times (Felsenstein 1985). Phylogenetic trees were visualized using TreeExplorer (Kumar et al. 2001) and TreeView (Page 1996).

RAPD analysis. RAPD analysis was performed using Ready-To-Go RAPD Analysis Beads ${ }^{\mathrm{TM}}$ (Amersham Biosciences). These commercial beads have been optimized for PCR amplifications and contain thermostable polymerase (Ampli$\mathrm{Taq}^{\mathrm{TM}}$ DNA polymerase and Stoffel fragment), dNTPs $(0.4 \mathrm{mM}$ each), BSA $(2.5 \mu \mathrm{g})$, and buffer $(3 \mathrm{mM} \mathrm{MgCl}, 30 \mathrm{mM} \mathrm{KCl}$ and $10 \mathrm{mM}$ Tris, $\mathrm{pH} 8.3$, in a $25 \mu \mathrm{l}$ reaction volume). Twenty-five pmol of the selected arbitrary primer, 50 ng of template DNA and molecular biology grade water was added to achieve the $25 \mu \mathrm{l}$ reaction volume.

The amplification was performed in a MJ Research PTC-200 thermal cycler (MJ Research) under the following conditions; an initial denaturation at $95^{\circ} \mathrm{C}$ for $5 \mathrm{~min}$, followed by 45 cycles consisting of denaturation at $95^{\circ} \mathrm{C}$ for $1 \mathrm{~min}$, annealing at $36^{\circ} \mathrm{C}$ for $1 \mathrm{~min}$, and extension at $72^{\circ} \mathrm{C}$ for $2 \mathrm{~min}$, with a final extension at $72^{\circ} \mathrm{C}$ for $5 \mathrm{~min}$. The RAPD products were electrophoresed in a $1.5 \%$ agarose gel containing $0.5 \mu \mathrm{g} \mathrm{ml}^{-1}$ of ethidium bromide and a DNA molecular weight marker, GeneRuler 100 bp DNA Ladder Plus (Fermentas International) was used to determine RAPD fragment sizes. All agarose gels were visualized under UV light and images captured (.TIFF files) by a gel documentation system, GeneSnap 4.0 (Syngene). Images of agarose gels were analyzed by manually transforming all DNA fragments into a binary data matrix. Individual DNA fragments obtained using a given primer were scored as present (1) or absent (0) for each isolate. All reproducibly visible DNA fragments ( $\mathrm{n}=3$, for each isolate and primer combination) were included in the RAPD analysis. The data obtained from all 3 RAPD primers (1,5 and 6) were combined into a single data matrix. All computations were performed with the program FreeTree (Pavalíček et al. 1999, Hampl et al. 2001). Genetic distances (d) for each isolate were calculated from Nei-Li's coefficient of similarity (s), where $d=(1-s)$ (Nei \& Li 1979). Phylogenetic trees were constructed from the similarity matrix by neighbor-joining (Saitou \& Nei 1987) incorporating 1000 bootstrap resamplings (Felsenstein 1985). Phylogenetic trees were visualized using TreeView (Page 1996).

\section{RESULTS}

\section{Phenotypic characterization}

All isolates of lobster origin and the single nonmarine isolate ATCC 700406 satisfied the criteria set out by Stewart et al. (1966) for Aerococcus viridans var. homari: pinpoint colonies of Gram-positive cocci, arranged singly, paired, or in tetrads or other small

Table 2. Phenotypic differences among Aerococcus viridans var. homari isolates and a non-marine $A$. viridans (ATCC 700406). $\beta$ GLU: $\beta$-glucosidase; $\beta$ GUR: $\beta$-glucuronidase; HIPP: hydrolysis of hippurate; GAL: fermentation of galactose; Inulin: fermentation of inulin; Starch: hydrolysis of starch; TEL: tolerance to $0.04 \%$ tellurite

\begin{tabular}{|lccccccc|}
\hline Isolate & $\beta$ GLU & $\beta$ GUR & HIPP & GAL & Inulin & Starch & TEL \\
\hline ATCC 10400 & - & + & + & + & + & - & + \\
ATCC 29838 & - & + & + & + & + & - & + \\
Rabin & - & + & + & + & + & - & + \\
Newfoundland & - & + & + & + & + & - & + \\
Maine & - & + & + & + & + & - & + \\
NVI 1030 & - & + & + & + & + & - & + \\
NVI 1032 & - & + & + & + & + & - & + \\
37R & + & - & - & + & - & - & + \\
88B & - & + & + & + & + & - & + \\
ATCC 700406 & - & - & + & - & - & + & - \\
\hline
\end{tabular}


groups but not in chains or grape-like clusters; hemolytic on BA (sheep); catalase-negative. All isolates also satisfied the criteria for A. viridans given by Bergey's manual of determinative bacteriology: nonmotile; growth at $10^{\circ} \mathrm{C}$ but not at $45^{\circ} \mathrm{C}_{\text {; }}$ growth at pH 9.6, in $10 \% \mathrm{NaCl}$, and in $40 \%$ bile; gelatin was not liquified; nitrate was not reduced; and production of acid from oxidative and fermentative metabolism of glucose (Holt et al. 1994, p. 527). Production of PYR, no production of LAP and sensitivity to vancomycin were consistent with $A$. viridans (Ruoff 2003).

There was phenotypic clustering of the virulent Aerococcus viridans var. homari isolates based on $\beta$ glucosidase, $\beta$-glucuronidase, hippurate, galactose, inulin, tellurite, and starch hydrolysis (Table 2). However, there was no clustering of the avirulent and nonmarine $A$. viridans group, but the variability within this group clearly differentiated them from the virulent group. No phenotypic tests were specific for the virulent strains. These results are in agreement with Wiik et al. (1986).

\section{S rRNA gene analysis}

A total of 1419 nucleotides (nt) of unambiguous sequence information was generated from the universal primers (BSF-8/20 and BSR-1541/20) for all 7 Aerococcus viridans var. homari isolates, the 2 avirulent $A$. viridans-like cocci and the non-marine $A$. viridans (ATCC 700406). Therefore, approximately $26 \mathrm{nt}$ and $59 \mathrm{nt}$ of sequence are missing from the $5^{\prime}$ and $3^{\prime}$ ends of the gene (between the primers), respectively, in relation to the Escherichia coli nucleotide positions. The GenBank accession numbers are as follows: $A$. viridans var. homari NVI 1030 (AY707775), NVI 1032 (AY707776), ATCC 10400 (AY707777), ATCC 29838 (AY707778), Maine (AY707780), Newfoundland (AY707781), Rabin (AY707782), A. viridans-like cocci 37R (AY707773) and 88B (AY707774) and A. viridans ATCC 700406 (AY707779).

The 7 Aerococcus viridans var. homari isolates, the 2 avirulent $A$. viridans-like cocci and the non-marine $A$. viridans (ATCC 700406) isolates from the present study exhibited 99.9 to $100 \%$ similarity over 1419 nucleotides (Table 3). The 16S rRNA sequences of $A$. viridans var. homari isolates ATCC 10400, ATCC 29838, Rabin, Newfoundland, Maine, 1030, 1032 are identical to that of Pediococcus urinaeequi (Table 3). The A. viridans-like cocci $37 \mathrm{R}$ and $88 \mathrm{~B}$ isolates share the same 16S rRNA sequence with the non-marine strain ATCC 700406 and the Lake Vanda (Antarctica) isolate Aerococcus sp. LV 65.5:W1 (Table 3).

The Aerococcus viridans var. homari isolates only differ from each other at 1 nucleotide position; ATCC

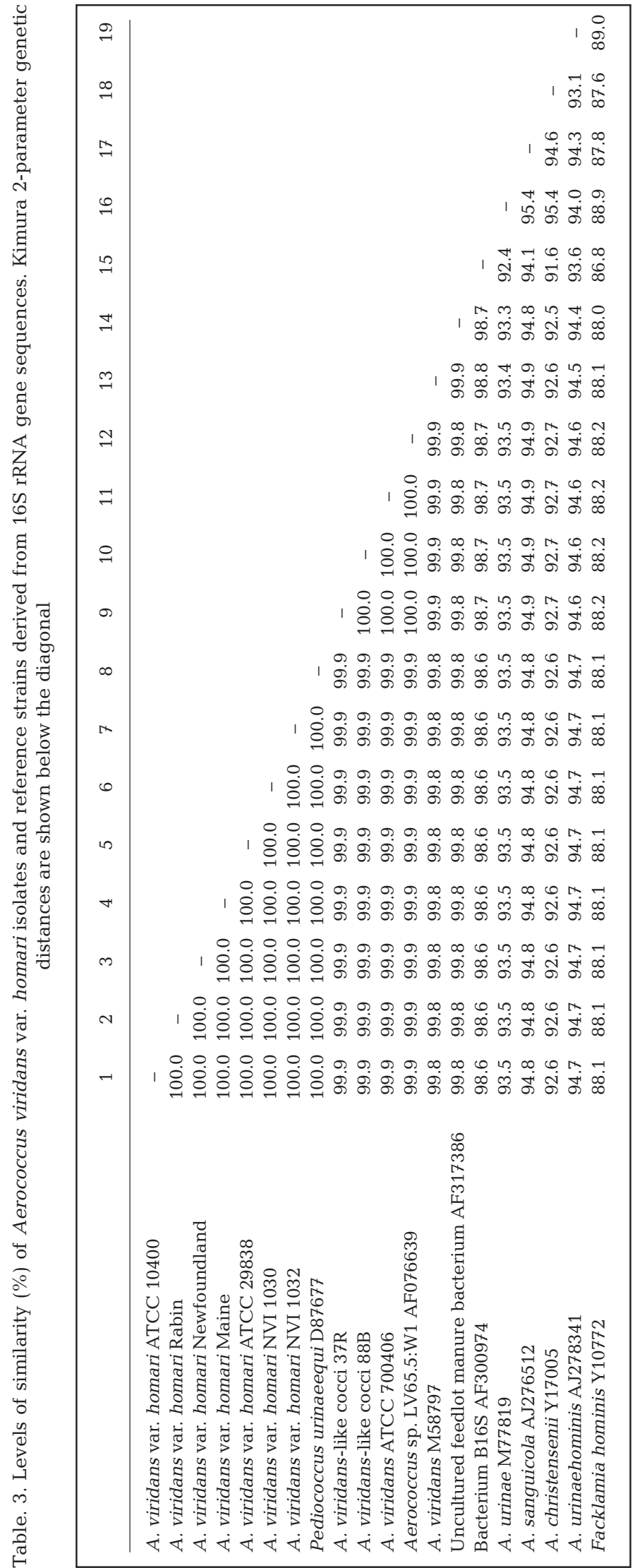




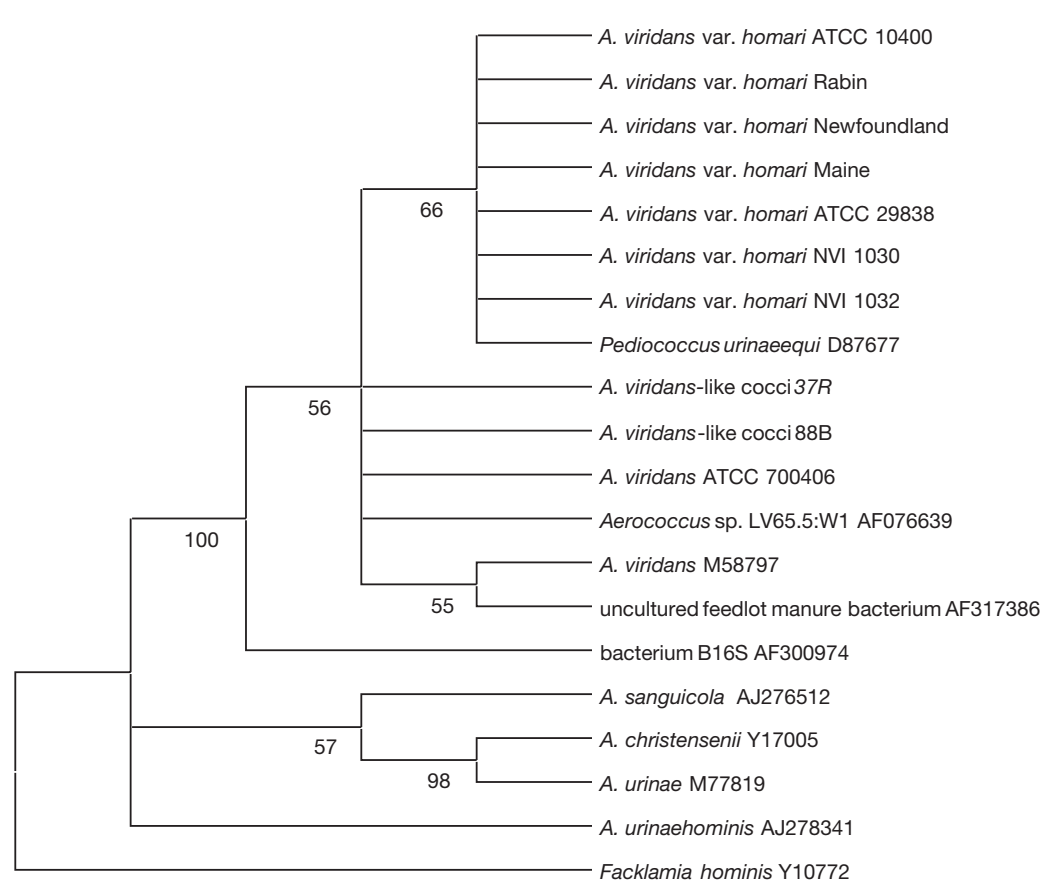

Fig. 1. Aerococcus viridans var. homari. Neighbor-joining tree based on the alignment of 1238 nucleotides of the 16S rRNA gene sequences indicating the phylogenetic position of the $A$. viridans var. homari isolates. Numbers at nodes are the percentages of bootstrap replications (only values greater than $50 \%$ are shown). GenBank accession numbers are given beside species names

cocci 37R was performed using each of the 6 arbitrary primers provided in the commercial kit. Primers (1,5 and 6) were selected for further analysis with all strains, based on producing the most discriminatory DNA fingerprint profile (number of DNA fragments and the best differential pattern). The other primers (2, 3 and 4$)$ gave a small number of DNA fragments or very poor amplification and were not considered further in the present study (data not shown). The reproducibility of the results was verified by repeating all RAPD reactions for each strain at least 3 times. No significant differences were observed in the patterns, although some bands varied in intensity.

The DNA fingerprint profiles from all 3 primers revealed that the 7 recognized Aerococcus viridans var. homari lobster isolates were identical (Fig. 2). Two other isolates previously documented as avirulent A. viridanslike cocci (37R and 88B) isolated from lobsters had DNA fragment patterns that were more similar to each other

10400, ATCC 29838, Rabin, Newfoundland, Maine, NVI 1030, NVI 1032 have a G at nucleotide position 150 (of the 1419) while the $A$. viridans-like cocci $37 \mathrm{R}$ and $88 \mathrm{~B}$ have an $\mathrm{A}$ at the same position.

A phylogenetic analysis based on 1238 nucleotides from the 16S rRNA gene of the Aerococcus viridans isolates from this study was performed by comparison with 10 reference sequences obtained from GenBank. A neighbor-joining bootstrap-consensus tree (1000 iterations and reported bootstrap values $>50 \%$ ) was constructed (Fig. 1). The A. viridans isolates are supported ( $100 \%$ bootstrap value) as a monophyletic clade within the genus Aerococcus (Fig. 1). The association of the A. viridans var. homari isolates with Pediococcus urinaeequi was supported by a bootstrap value of $66 \%$ (Fig. 1). The A. viridans-like cocci $37 \mathrm{R}$ and $88 \mathrm{~B}$ isolated from lobsters are more closely associated with the nonmarine A. viridans isolate ATCC 700406 and the Lake Vanda (Antarctica) isolate Aerococcus sp. LV 65.5:W1 (Fig. 1). A phylogenetic tree constructed using maximum parsimony gave a similar result (not shown).

\section{RAPD analysis}

Initially, RAPD analysis on Aerococcus viridans var. homari strains ATCC 10400 and the A. viridans-like than to either the recognized $A$. viridans var. homari lobster isolates or the non-marine $A$. viridans isolate (Fig. 2 ).

A total of 71 reproducible DNA fragments from all 3 primers, ranging in size from 350 to $2100 \mathrm{bp}$ were used to build the similarity matrix for the 10 Aerococcus viridans isolates and 1 Escherichia coli strain (Fig. 3). The Aerococcus isolates formed 2 assemblages with the 7 A. viridans var. homari lobster isolates being supported with bootstrap values of $100 \%$ and a weaker association of the non-marine isolate with the $A$. viridans-like cocci, 37R and 88B (mean bootstrap value, 43\%) (Fig. 3).

\section{DISCUSSION}

This study describes the genetic characterization of 7 isolates of Aerococcus viridans var. homari and 2 avirulent $A$. viridans-like cocci isolated from American lobsters originating on the Atlantic Coast of North America. To resolve the phylogenetic affinities of the A. viridans-like cocci and to confirm the identity of the A. viridans var. homari strains, all isolates were initially characterized by sequencing their 16S rRNA genes. This confirmed unequivocally the identity of all 9 isolates as members of the monophyletic clade $A$. viri- 

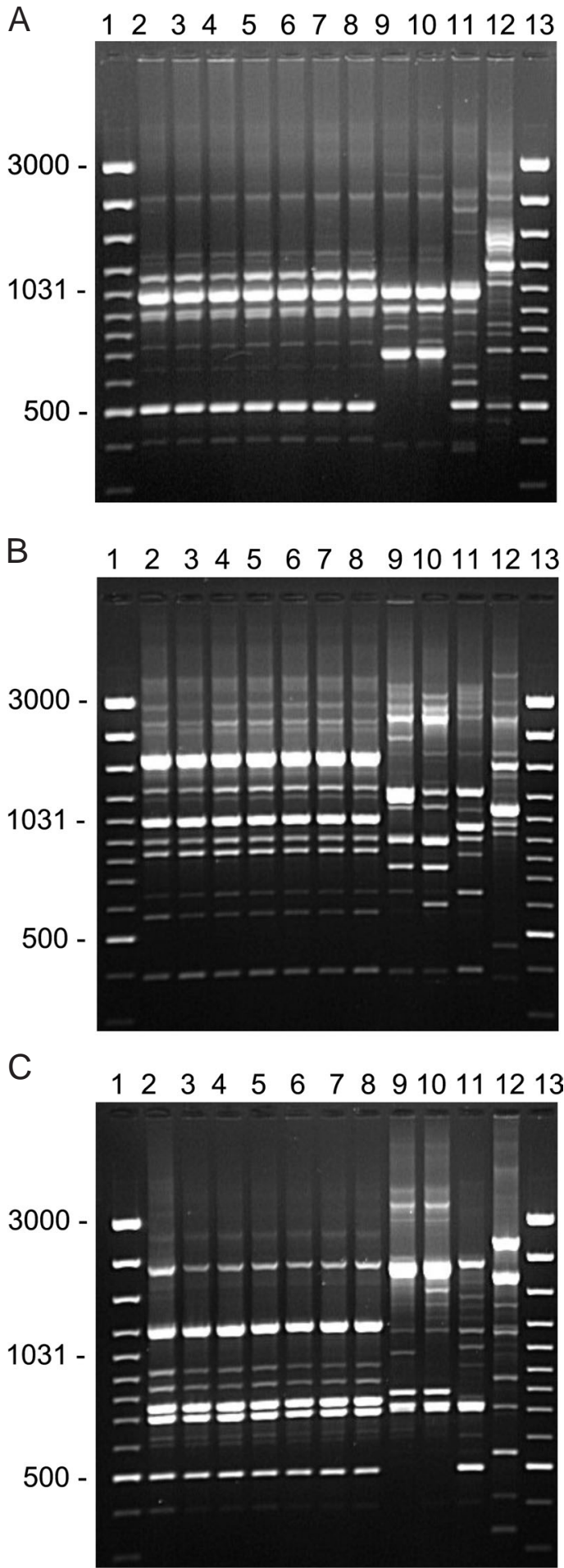

Fig. 2. Aerococcus viridans var. homari isolates RAPD profiles. (A) RAPD primer 1; (B) RAPD primer 5; (C) RAPD primer 6. Lanes: 1, GeneRuler 100 bp DNA Ladder Plus (sizes of specific bands in base pairs noted on left); 2, ATCC 10400; 3 , Rabin; 4, Newfoundland; 5, Maine; 6, ATCC 29838; 7, NVI 1030; 8, NVI 1032; 9, 37R; 10, 88B; 11, ATCC 700406; 12, Escherichia coli (strain BL21); 13, GeneRuler 100 bp DNA Ladder Plus dans. The placement of Pediococcus urinaeequi within the A. viridans clade was noted earlier (Collins et al. 1990, Christensen et al. 1997). However, the present analysis suggests that $P$. urinaeequi may be an $A$. viridans var. homari strain based on having an identical 16S rRNA sequence. Currently, there is no accepted cut-off value for $16 \mathrm{~S}$ rRNA sequence similarity that defines a species, but the majority of related species within a genus differ by at least $1 \%$ or more of the nucleotide positions (Fox et al. 1992, Stackebrandt \& Goebel 1994, Drancourt et al. 2000, Song et al. 2003). Using this criterion, all members of the A. viridans clade belong to the same species since they differ at only 1 nucleotide position (sequence similarity values of 99.8 to $100 \%$ ).

A previous genotypic comparison of Aerococcus viridans var. homari based on DNA hybridization indicated a close relationship of all isolates from gaffkemic lobsters (80 to $100 \%$ hybridized DNA) but questioned the inclusion of the $A$. viridans-like cocci in the same group as the lobster pathogen, because of low hybridization values of 48 to $56 \%$ (Wiik et al. 1986). Strains of the human urinary tract pathogen, Aerococcus urinae, can be separated into 2 biotypes based on phenotypic differences in esculin hydrolysis. Yet, the A. urinae biotypes are 98.2 to $99.3 \%$ similar based on their 16S rRNA sequences and show considerable variation in DNA reassociation (62 to $81 \%$ hybridized DNA) (Christensen et al. 1997). The genotypic heterogeneity demonstrated by DNA hybridization differences between A. urinae led Christensen et al. (1997) to suggest that the species may comprise 2 or more subspecies. Therefore, although the A. viridans var. homari 16S rRNA sequences are very similar, the DNA hybridization data (Wiik et al. 1986) indicates that there is considerable genetic variation between the different strains. Thus, a significant genetic variation at the strain level may be a common feature of the genus Aerococcus.

The RAPD analysis indicated the presence of 2 distinct Aerococcus viridans var. homari subtypes. Subtype 1 included the 7 previously recognized $A$. viridans var. homari isolates which have the same DNA fingerprint profile irrespective of the primer employed, and therefore, constitute a genetically homogeneous group regardless of their geographical, temporal or virulence differences. Subytpe 2 contained only the 2 naturally occurring avirulent $A$. viridans-like cocci. These $A$. viridans-like cocci exhibited distinct RAPD patterns from the other $A$. viridans var. homari isolates (subtype 1) but clustered separately with the non-marine A. viridans strain.

The homogeneity of the Aerococcus viridans var. homari subtype 1 was surprising, given they are temporally quite disparate (1947 to 2000) and found over 


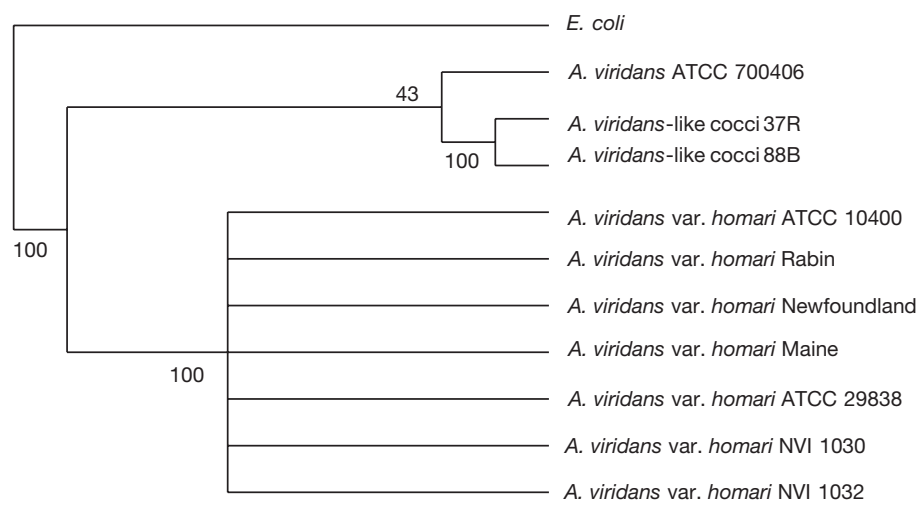

Fig. 3. Aerococcus viridans var. homari. Neighbor-joining tree constructed using 71 RAPD characters indicating the phylogenetic position of the $A$. viridans var. homari isolates. Numbers at nodes are percentages of bootstrap replications

the geographic range of the present study (Massachusetts to Newfoundland). Historically, subtype 1 contains the 2 strains that have been the focus of the greatest amount of research, ATCC 10400 (Snieszko \& Taylor 1947) and Rabin strain (Rabin \& Hughes 1968, Stewart et al. 1966). The identical DNA fingerprint profile of subtype 1 may be explained by one or more of the following: (1) the persistence of the bacteria in a stable marine environment; (2) the dispersal of the bacteria by water currents within the Atlantic region; (3) the natural history of an evolutionarily long-standing host-pathogen relationship; (4) the importation of lobsters from different regions for processing, which may lead to the movement of infected lobsters or asymptomatic carriers. The pathogens could potentially spread to susceptible populations through waste water run-off from processing plants. Similar scenarios have been implicated in the spread of fish diseases and for the appearance of pathogens with the same DNA fingerprint pattern in different countries (Hänninen \& Hirvelä-Koski 1999, Ravelo et al. 2003).

Stewart et al. (2004) have recently shown that virulence in Aerococcus viridans var. homari can be induced by culturing avirulent strains in the presence of sterile lobster hemolymph serum. The induction of virulence coincides with the restoration of the polysaccharide capsule, which in turn prevents agglutination and killing by lobster phagocytes during infection. The variation in capsule thickness under different culture conditions had been noted earlier (Hitchner \& Sniezko 1947, Stewart 1984). The explanation of induced virulence is consistent with the current RAPD analysis of $A$. viridans var. homari strains in which no genetic variation was observed between the avirulent and virulent members of subtype 1 . However, in the context of the study of Stewart et al. (2004), our RAPD results also indicate that there are at least 2 distinctly different genetic strains of $A$. viridans var. homari on the Atlantic Coast of North America that have the potential to cause disease in lobsters. Since the $A$. viridans-like cocci (which are $A$. viridans var. homari) share an identical $16 \mathrm{~S}$ rRNA sequence with the non-marine strain ATCC 700406 and the Lake Vanda (Antarctica) isolate Aerococcus sp. LV 65.5:W1, this implies that there potentially are more strains of $A$. viridans var. homari than have been previously recognized.

Previous work on the development of an indirect fluorescent antibody technique (IFAT) for detection of $A$. viridans var. homari documented differences in IFAT staining between virulent (Rabin, NVI 1030, NVI 1032) and avirulent strains (ATCC 10400, 37R and 88B) that were correlated with variation in capsule thickness (Marks et al. 1992). The results of our genetic characterization of Aerococcus viridans var. homari, combined with the studies of Stewart et al. (2004) and Marks et al. (1992), suggest that the variation observed in virulence among the different strains of $A$. viridans var. homari is probably a function of changes in gene expression that result in antigenic variation (protein or carbohydrate) in the context of the environment. It would be interesting to extend the present study to include more isolates from similar locations to assess both the local, regional and global genetic variation that may exist within $A$. viridans var. homari and to explore the potential variation in pathogenesis that may exist within the 2 A. viridans var. homari subtypes.

In summary, the combination of $16 \mathrm{~S}$ rRNA gene sequencing and RAPD analysis has revealed that all 9 Aerococcus viridans var. homari isolates are members of the monophyletic $A$. viridans clade and that the lobster pathogen can be separated into at least 2 subtypes on the Atlantic coast of North America. On this basis, RAPD analysis represents a useful method for discriminating molecular subtypes for both intraspecific classification and epidemiological investigations of $A$. viridans var. homari.

Acknowledgements. We thank Dr. J. E. Stewart for many thoughtful discussions during the study and for providing comments on the manuscript. The authors also wish to thank Drs. A. Battison and J. Lavallée for constructive comments on the manuscript. Funding for the Canadian Lobster Health Research Project delivered by the AVC Lobster Science Centre represents a consortium of private sector companies, fishermen's organizations, First Nations, provincial and federal government agencies, including the Atlantic Innovation Fund through the Atlantic Canada Opportunities Agency. 


\section{LITERATURE CITED}

Aguirre M, Collins MD (1992) Phylogenetic analysis of some Aerococcus-like organisms from urinary tract infections: description of Aerococcus urinae sp. nov. J Gen Microbiol 138:401-405

Allen AE, Booth MG, Frischer ME, Verity PG, Zehr JP, Zani S (2001) Diversity and detection of nitrate assimilation genes in marine bacteria. Appl Environ Microbiol 67:5343-5348

Audouin J, Léglise M (1971) Note préliminaire sur la présence de Gaffkya homari dans le sang des homards stockés dans les vivers de la région de Roscott. ICES (Int Counc Explor Sea) Shellfish Comm K:1-6

Bosley GS, Wallace PL, Moss CW, Steigerwalt AG, Brenner DJ, Swenson JM, Hebert GA, Facklam RR (1990) Phenotypic characterization, cellular fatty acid composition, and DNA relatedness of aerococci and comparison to related genera. J Clin Microbiol 28:416-421

Bottger EC (1989) Rapid determination of bacterial ribosomal RNA sequences by direct sequencing of enzymatically amplified DNA. FEMS Microbiol Lett 53:171-176

Bratina BJ, Stevenson BS, Green WJ, Schmidt TM (1998) Manganese reduction by microbes from oxic regions of the lake vanda (Antarctica) water column. Appl Environ Microbiol 64:3791-3797

Christensen JJ, Whitney AM, Teixeira LM, Steigerwalt AG, Facklam RR, Korner B, Brenner DJ (1997) Aerococcus urinae: intraspecies genetic and phenotypic relatedness. Int J Syst Bacteriol 47:28-32

Cole JR, Chai B, Marsh TL, Farris RJ and 7 others (2003) The Ribosomal Database Project (RDP-II): previewing a new autoaligner that allows regular updates and the new prokaryotic taxonomy. Nucleic Acids Res 31:442-443

Collins MD, Williams AM, Wallbanks S (1990) The phylogeny of Aerococcus and Pediococcus as determined by $16 \mathrm{~S}$ rRNA sequence analysis: description of Tetragenococcus gen. nov. FEMS Microbiol Lett 58:255-262

Collins MD, Falsen E, Lemozy J, Akervall E, Sjoden B, Lawson PA (1997) Phenotypic and phylogenetic characterization of some Globicatella-like organisms from human sources: description of Facklamia hominis gen. nov., sp. nov. Int J Syst Bacteriol 47:880-882

Collins MD, Jovita MR, Hutson RA, Ohlén M, Falsen E (1999) Aerococcus christensenii sp. nov., from the human vagina. Int J Syst Bacteriol 49:1125-1128

Cowan ST, Steel KJ, Barrow GI, Feltham RKA (1993) Cowan and Steel's manual for the identification of medical bacteria. Cambridge University Press, Cambridge

Daly JS, Worthington MG, Brenner DJ, Moss CW and 6 others (1993) Rochalimaea elizabethae sp. nov. isolated from a patient with endocarditis. J Clin Microbiol 31:872-881

Drancourt M, Bollet C, Carlioz A, Martelin R, Gayral JP, Raoult D (2000) 16S ribosomal DNA sequence analysis of a large collection of environmental and clinical unidentifiable bacterial isolates. J Clin Microbiol 38:3623-3630

Facklam RR (1972) Recognition of Group D streptococcal species of human origin by biochemical and physiological tests. Appl Microbiol 23:1131-1139

Facklam R, Elliott JA (1995) Identification, classification, and clinical relevance of catalase-negative, Gram-positive cocci, excluding the streptococci and enterococci. Clin Microbiol Rev 8:479-495

Felsenstein J (1985) Confidence limits on phylogenies: an approach using the bootstrap. Evolution 39:783-791

Felsenstein J (1993) PHYLIP (Phylogeny Inference Package) version 3.5c, distributed by the author. Dept. of Genetics, University of Washington, Seattle, WA
Fertally SS, Facklam R (1987) Comparison of physiologic tests used to identify non-beta-hemolytic aerococci, enterococci, and streptococci. J Clin Microbiol 25:1845-1850

Fox GE, Wisotzkey JD, Jurtshcuk P, Jr (1992) How close is close: 16S rRNA sequence identity may not be sufficient to guarantee species identity. Int J Syst Bacteriol 42:166-170

Hall TA (1999) BioEdit: a user-friendly biological sequence alignment editor and analysis program for Windows 95/98/NT. Nucleic Acids Symp Ser 41:95-98

Hampl V, Pavlíček A, Flegr J (2001) Construction and bootstrap analysis of DNA fingerprinting-based phylogenetic trees with the freeware program FreeTree: application to trichomonad parasites. Int J Syst Evol Microbiol 51: 731-735

Hänninen ML, Hirvelä-Koski V (1999) Genetic diversity of atypical Aeromonas salmonicida studied by pulse-field gel electrophoresis. Epidemiol Infect 123:299-307

Hitchner ER, Snieszko SF (1947) A study of a microorganism causing a bacterial disease of lobsters. J Bacteriol 54:48 (Abstract)

Holt JG, Krieg NR, Sneath PHA, Staley JT, Williams ST (1994) Bergey's manual of determinative bacteriology, 9th edn. Williams \& Wilkins, Baltimore, MD

Hugenholz P, Huber T (2003) Chimeric 16S rDNA sequences of diverse origin are accumulating in the public databases. Int J Syst Evol Microbiol 53:289-293

Hyytiä E, Björkroth J, Hielm S, Korkeala H (1999) Characterisation of Clostridium botulinum groups I and II by randomly amplified polymorphic DNA analysis and repetitive element sequence-based PCR. Int J Food Microbiol 48: $179-189$

Kelly K, Evans JB (1974) Deoxyribonucleic acid homology among strains of the lobster pathogen 'Gaffkya homari' and Aerococcus viridans. J Gen Microbiol 81:257-260

Kimura M (1980) A simple model for estimating evolutionary rates of base substitutions through comparative studies of nucleotide sequences. J Mol Evol 16:111-120

Kumar S, Tamura K, Jakobsen IB, Nei M (2001) MEGA2: Molecular Evolutionary Genetics Analysis software. Bioinformatics 12:1244-1245

Lawson PA, Falsen E, Ohlén M, Collins MD (2001a) Aerococcus urinaehominis sp. nov., isolated from human urine. Int J Syst Evol Microbiol 51:683-686

Lawson PA, Falsen E, Truberg-Jensen K, Collins MD (2001b) Aerococcus sanguicola sp. nov., isolated from a human clinical source. Int J Syst Evol Microbiol 51:475-479

Lemos ML, Toranzo AE, Barja J (1985) Modified medium for the oxidation-fermentation test in the identification of marine bacteria. Appl Environ Microbiol 49:1541-1543

MacFaddin JF (1980) Biochemical tests for identification of medical bacteria, 2nd edn. Williams \& Wilkins, Baltimore, MD

Magariños B, Toranzo AE, Barja JL, Romalde JL (2000) Existence of two geographically-linked clonal lineages in the bacterial fish pathogen Photobacterium damselae subsp. piscicida evidenced by random amplified polymorphic DNA analysis. Epidemiol Infect 125:213-219

Maidak BL, Cole JR, Parker CT Jr, Garrity GM and 10 others (1999) A new version of the RDP (Ribosomal Database Project). Nucleic Acids Res 27:171-173

Maidak BL, Cole JR, Lilburn TG, Parker CT Jr and 6 others (2001) The RDP-II (Ribosomal Database Project). Nucleic Acids Res 29:173-174

Marks LJ, Stewart JE, Håstein T (1992) Evaluation of an indirect fluorescent antibody technique for detection of Aerococcus viridans (var.) homari, pathogen of homarid lobsters. Dis Aquat Org 13:133-138 
Nei M, Li WH (1979) Mathematical model for studying genetic variation in terms of restriction endonucleases. Proc Natl Acad Sci USA 76:5269-5273

Olive DM, Bean P (1999) Principles and applications of methods for DNA-based typing of microbial organisms. J Clin Microbiol 37:1661-1669

Olsen GJ, Woese CR (1993) Ribosomal RNA: a key to phylogeny. FASEB J7:113-123

Page RD (1996) TreeView: an application to display phylogenetic trees on personal computers. Comput Appl Biosci 12: 357-358

Pavalíček A, Hrda S, Flegr J (1999) Free Tree-freeware program for construction of phylogenetic trees on the basis of distance data and bootstrap/jackknife analysis of the tree robustness. Application in the RAPD analysis of genus Frenkelia. Folia Biol (Praha) 45:97-99

Rabin H, Hughes JT (1968) Studies on host-parasite relationships in gaffkemia. J Invertebr Pathol 10:335-344

Ravelo C, Magariños B, López-Romalde S, Toranzo AE, Romalde JL (2003) Molecular fingerprinting of fish-pathogenic Lactococcus garvieae strains by random amplified polymorphic DNA analysis. J Clin Microbiol 41:751-756

Romalde JL, Magariños B, Villar C, Barja JL, Toranzo AE (1999) Genetic analysis of turbot pathogenic Streptococcus parauberis strains by ribotyping and random amplified polymorphic DNA. FEMS Microbiol Lett 459:297-304

Romalde JL, Castro D, Magariños B, López-Cortes L, Borrego JJ (2002) Comparison of ribotyping, randomly amplified polymorphic DNA, and pulsed-field gel electrophoresis for molecular typing of Vibrio tapetis. System Appl Microbiol 25:544-550

Ruoff KL (2003) Aerococcus, Abiotrophia, and other infrequently isolated aerobic catalase-negative, gram-positive cocci. In: Murray PR, Baron EJ, Jorgensen GH, Pfaller MA, Yolken RH (eds) Manual of clinical microbiology, 8th edn. Am Soc Microbiol, Washington, DC, p 434-444

Saitou N, Nei M (1987) The neighbor-joining method: a new method for reconstructing phylogenetic trees. Mol Biol Evol 4:406-425

Sambrook J, Fritsch EF, Maniatis T (1989) Molecular cloning: a laboratory manual, 2nd edn. Cold Spring Harbor Laboratory Press, Cold Spring Harbor, NY

Snieszko SF, Taylor CC (1947) A bacterial disease of the lobster (Homarus americanus). Science 105:500

Soll DR (2000) The ins and outs of DNA fingerprinting the infectious fungi. Clin Microbiol Rev 13:332-370

Editorial responsibility: Timothy Flegel,

Bangkok, Thailand
Song Y, Liu C, McTeague M, Finegold SM (2003) 16S ribosomal DNA sequence-based analysis of clinically significant grampositive anaerobic cocci. J Clin Microbiol 41:1363-1369

Stackebrandt E, Goebel BM (1994) Taxonomic note: a place for DNA-DNA reassociation and 16S rRNA sequence analysis in the present species definition in bacteriology. Int J Syst Bacteriol 44:846-849

Stewart JE (1980) Diseases. In: Phillips BF, Cobb JS (eds) The biology and management of lobsters, Vol 1. Physiology and behavior. Academic Press, New York, p 301-342

Stewart JE (1984) Lobster diseases. Helgol Meeresunters 37 : $243-254$

Stewart JE (1993) Infectious diseases of marine crustaceans. In: Couch JA, Fournie JW (eds) Pathobiology of marine and estuarine organisms. Advances in fisheries science. CRC Press, Boca Raton, FL, p 319-342

Stewart JE, Cornick JW, Spears DI (1966) Incidence of Gaffkya homari in natural lobster (Homarus americanus) populations of the Atlantic region of Canada. J Fish Res Board Can 23:1325-1330

Stewart JE, Cornick JW, Zwicker BM, Arie B (2004) Studies on the virulence of Aerococcus viridans (var.) homari, the causative agent of gaffkemia, a fatal disease of homarid lobsters. Dis Aquat Org 60:149-155

Weisburg WG, Barns SM, Pelletier DA, Lane DJ (1991) 16S ribosomal DNA amplification for phylogenetic study. J Bacteriol 173:697-703

Welsh J, McClelland M (1990) Fingerprinting genomes using PCR with arbitrary primers. Nucleic Acids Res 18: 7213-7218

Wiik R, Torsvik V, Egidius E (1986) Phenotypic and genotypic comparisons among strains of the lobster pathogen Aerococcus viridans and other marine Aerococcus viridans-like cocci. Int J Syst Bacteriol 36:431-434

Williams JG, Kubelik AR, Livak KJ, Rafalsky JA, Tingey SV (1990) DNA polymorphisms amplified by arbitrary primers are useful genetic markers. Nucleic Acids Res 18: $6531-6535$

Wood PC (1965a) A preliminary note on gaffkemia investigations in England. Rapp P-V Réun Cons Perm Int Explor Mer 156:303-304

Wood PC (1965b) Gaffkaemia, the blood disease of lobsters. J Gen Microbiol 41:(3) XXVIII

Wuyts J, Van de Peer Y, Winkelmans T, De Wachter R (2002) The European database on small subunit ribosomal RNA. Nucleic Acids Res 30:183-185

Submitted: August 31, 2004; Accepted: October 13, 2004

Proofs received from author(s): January 14, 2005 